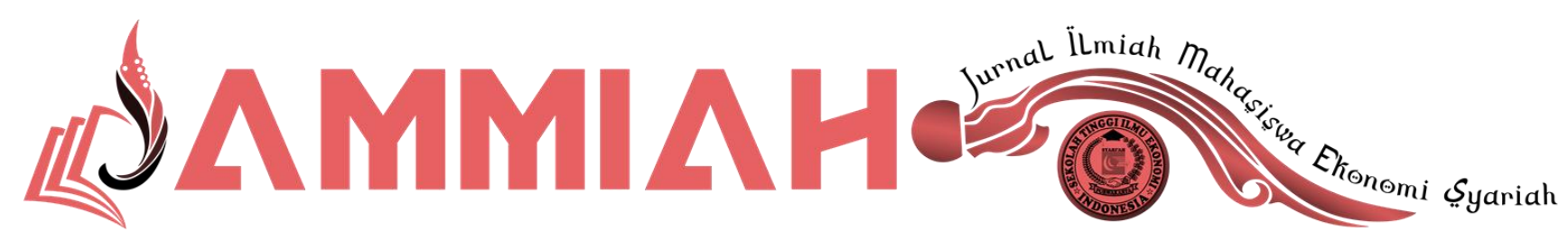

Volume 1 Nomor 2, September 2021

\title{
Mekanisme Pembiayaan Pemilikan Kendaraan Bermotor iB Maslahah Di PT. Bank BJB Syariah KCP Cikampek
}

\author{
Nita Septiana1, Lita Anis Setya², Siti Rohmat ${ }^{3}$ \\ 1,2,3 Sekolah Tinggi Ilmu Ekonomi Syariah (STIES) Indonesia Purwakarta \\ Jalan Veteran No. 150-152 Ciseureuh Purwakarta Jawa Barat Indonesia 41118 \\ 1nitaseptiana531@gmail.com \\ 2litaanissetya24@gmai.com \\ ${ }^{3}$ sitirohmat@gmail.com
}

\section{ABSTRAK}

Penelitian ini tentang mekanisme pembiayaan kepemilikan kendaraan bermotor Produk ini merupakan produk baru dalam Pegadaian Syariah. Produk ini akan sangat membantu nasabah yang ingin memiliki kendaraan bermotor, baik motor maupum mobil. Adapun tujuan penelitian ini adalah untuk mengetahui sistem pembiayaan kepemilikan kendaraan bermotor dan untuk menganalisa dari sudut pandang hukum ekonomi Islam tentang produk pembiayaan (PPKB). Hasil penelitian ini menjelaskan bahwa pembiayaan pemilikan kendaraan sepeda motor yang dimana calon nasabah harus memberikan simpanan wajib dan pokok sebagai pendaftaran calon nasabah Bank BJB Syariah, kemudian melengkapi persyaratan-persyaratan yang ada, dan juga melengkapi identitas diri si pemohon pembiayaan. pendaftaran Nasabah baru dengan memberikan simpanan wajib dan pokok serta memberikan uang muka sebesar 30\% dari jumlah harga sepeda motor. Sisa $70 \%$ di angsur sesuai dengan kesepakatan di awal antara nasabah dengan pihak Bank.

Kata Kunci : Mekanisme, Pembiayaan, Pemilikan Kendaraan Bermotor iB Maslahah 


\section{ABSTRACT}

This research is about the mechanism of financing for motorized vehicle ownership. This product is a new product in the Sharia Pawnshop. This product will be very helpful for customers who want to own a motorized vehicle, either a motorcycle or a car. The purpose of this study is to determine the financing system for motorized vehicle ownership and to analyze from the point of view of Islamic economic law regarding financing products (PPKB). The results of this study explain that the financing of motorcycle ownership in which prospective customers must provide mandatory and principal savings as a registration of prospective customers of Bank BJB Syariah, then complete the existing requirements, and also complete the identity of the applicant for financing. registration of new customers by providing mandatory and principal savings and providing an advance of $30 \%$ of the total price of the motorcycle. The remaining $70 \%$ is paid in installments according to the initial agreement between the customer and the Bank.

Keywords: Mechanism, Financing, Motorized Vehicle Ownership iB Maslahah

\section{PENDAHULUAN}

Dari tahun ketahun, dunia kerja mengalami perubahan. Ini diakibatkan oleh era globalisasi yang terjadi saat ini. Dalam era globalisasi ini banyak masalah yang timbul diberbagai kalangan, dan semua masalah muncul karena perbedaan pendapat antara manusia satu dengan yang lainnya. Dari sekian banyak masalah, yang paling sering dihadapi oleh setiap masyarakat adalah sulitnya mencari lahan pekerjaan. ${ }^{1}$

Kita sebagai manusia yang memiliki Visi, Misi, Tujuan dan Strategi, wawasan ke depan hendaknya tidak melupakan akan perkembangan teknologi yang mempunyai arti penting dalam suatu pekerjaan, karena hal tersebut menuntut kita untuk mengikuti perkembangan zaman agar tidak ketinggalan dengan informasi yang ada. Saat ini ilmu pengetahuan dan perkembangan teknologi dengan sangat pesat serta dukungan dari media informasi yang sedemikian rupa sehingga mengakibatkan perubahan pola hidup di berbagai kalangan masyarakat tanpa kelas. ${ }^{2}$

Tujuan kegiatan ini dilaksanakan sebagai salah satu bentuk pengaplikasian ilmu-ilmu secara teoritis yang telah didapat selama perkuliahan yang pengimplementasiannya dilakukan dalam kegiatan ini. Kegiatan ini dapat pula memupuk disiplin kerja dan profesionalisme dalam bekerja agar dapat mengenal

${ }^{1}$ Muhammad Syarif. Hidayatulloh, "Mekanisme Pembiayaan Kepemilikan Kendaraan Sepeda Motor Di KJKS BMT Al-Hikmah Ungaran Cabang Bandungan" (Uin Walisongo, 2016).

${ }^{2}$ Freddy Rangkuti, Personal Swot Analysis Peluang Di Balik Kesulitan (Jakarta: Gramedia, 2016).

JAMMIAH (Jurnal Ilmiah Mahasiswa Ekonomi Syariah), Volume 1, Nomor 2, September 2021 
dunia atau lingkungan kerja yang akan bermanfaat bagi mahasiswa setelah menyelesaikan perkuliahan.

Penelitian ini tentang mekanisme pembiayaan kepemilikan kendaraan bermotor Produk ini merupakan produk baru dalam Pegadaian Syariah. Produk ini akan sangat membantu nasabah yang ingin memiliki kendaraan bermotor, baik motor maupum mobil. Tapi produk ini hanya dibataskan kepada karyawan saja. Namun seiring dengan perkembangannya produk Amanah ini ditawarkan di berbagai lembagalembaga keuangan lainya. Hal ini tentu saja menjadi tantangan dan masalah bagi bank syariah, terutama dalam hal peningkatan pendapatan. Penelitian ini sudah dilakukan oleh peneliti sebelumnya seperti yang dilakukan oleh Nur Muhammad Lakdar Baluntu ${ }^{3}$. Adapun tujuan penelitian ini adalah untuk mengetahui sistem pembiayaan kepemilikan kendaraan bermotor dan untuk menganalisa dari sudut pandang hukum ekonomi Islam tentang produk pembiayaan (PPKB). Kemudian yang berkaitan dengan kegunaan penelitian ini yakni bermanfaat untuk menambah wawasan dan pengetahuan dan dipergunakan sebagai pertimbangan dan acuan bagi kalangan umat Islam dalam praktek pembiayaan kendaraan bermotor.

Dalam penelitian ini permasalahan yang sering muncul pada pembiayaan pemilikan kendaraan bermotor adalah masalah angsuran yang tidak kunjung dibayar setelah jatuh tempo oleh pihak nasabah(konsumen) atau biasa disebut dengan kredit macet. Dalam penyelesaian kredit macet ini Bank Bjb syariah akan bertindak sesuai dengan isi perjanjian yang tertuang di dalam kontrak perjanjian pembiayaan kepemilikan kendaraan bermotor yang telah disetujui oleh kedua belah pihak ${ }^{4}$. Peneliti ini mengaji lebih dalam terkait mekanisme pembiayaan kepemilikan kendaraan bermotor.

\section{A.Tinjauan Umum Tentang Bank}

\section{TINJAUAN PUSTAKA}

Bank dikenal sebagai lembaga keuangan yang kegiatan utamanya menerima simpanan giro, tabungan, dan deposito. Di samping itu, bank juga dikenal sebagai

${ }^{3}$ Nur Muhammad Lakdar Baluntu, “Minat Karyawan Dalam Pembiayaan Kepemilikan Kendaraan Bermotor Melalui Produk Amanah," Jurnal Ilmiah Al-Syir'ah 12.2. (2016).

${ }^{4}$ Ery Agus Lawadi, Aldo Agustinus; Busro, Achmad; Priyono, “Tinjauan Yuridis Terhadap Perjanjian Pembiayaan Kendaraan Bermotor Roda Empat Pada Lembaga Pembiayaan PT. BCA Finance," Diponegoro Law Journal 5.2: 1-14. (2016).

JAMMIAH (Jurnal Ilmiah Mahasiswa Ekonomi Syariah), Volume 1, Nomor 2, September 2021 
tempat untuk meminjam uang bagi masyarakat yang membutuhkannya. Berikut ini akan dijelaskan beberapa pengertian bank, yaitu ${ }^{5}$ :

1. Menurut Taswan

"Bank adalah sebuah lembaga atau perusahaan yang aktivitasnya menghimpun dana berupa giro, deposito, tabungan, dan simpanan yang lain dari pihak yang kelebihan dana (surplus unit) kemudian menempatkannya kembali kepada masyarakat yang membutuhkan dana (deficit unit) melalui penjualan jasa keuangan yang pada gilirannya dapat meningkatkan kesejahteraan rakyat banyak"

2. Menurut Undang-Undang Nomor 10 Tahun 1998 Tentang Perbankan "Bank adalah badan usaha yang menghimpun dana dari masyarakat dalam bentuk simpanan dan menyaurkannya kepada masyarakat dalam bentuk kredit dan atau bentuk-bentuk lainnya dalam rangka meningkatkan taraf hidup rakyat banyak".

3. Menurut Malayu Hasibuan bahwa "Bank adalah badan usaha yang kekayaannya terutama dalam bentuk asset keuangan (financial assets) serta bermotifkan profit dan juga sosial, jadi bukan hanya mencari keuntungan saja"7.

Dari berbagai definisi di atas, penulis menyimpulkan bahwa Bank merupakan lembaga keuangan yang menghimpun dana dari masyarakat dan menyalurkan kembali kepada masyarakat dan mempunyai peranan yang sangat penting dalam sistem perekonomian yang semakin bertumbuh, seiring dengan semakin bertumbuhnya kebutuhan masyarakat. Keberadaan perbankan ini semakin dibutuhkan oleh masyarakat dalam bentuk simpanan dan kredit maupun bentuk lainnya.

\section{B. Tinjauan Umum Tentang Bank Syariah}

Pengertian bank dalam islam atau bank syariah ialah "bank yang beroperasi dengan tidak bergantung pada bunga". Dalam definisi lain, perbankan syariah ialah

${ }^{5}$ Maikel Ch Ottay and Stanly W Alexander, "Analisis Laporan Keuangan Untuk Menilai Kinerja Keuangan Pada PT. BPR Citra Dumoga Manado," Jurnal Emba: Jurnal Riset Ekonomi, Manajemen, Bisnis Dan Akuntansi 3 3, no. 1 (2015).

${ }^{6}$ Jek Malensang, Dolina L Tampi, and Wilfried S Manoppo, "Analisa Tingkat Kesehatan Bank Berdasarkan Pendekatan RBBR (Risk Based Bank Rating) Pada PT. Bank SulutGo Periode 2015-2018," Jurnal Administrasi Bisnis (JAB) 9, no. 1 (2019): 82-89.

${ }^{7}$ Rosnaini Daga, Nurfatwa Ismail, and Bahtiar Maddatuang, “Analisis Efektivitas Program Mandiri Dagang Untung Pada Pt. Bank Mandiri (Persero), Tbk. Kanwil Regional X Sulawesi Dan Maluku," SEIKO: Journal of Management $\backslash \mathcal{E}$ Business 3, no. 3 (2020): 65-78.

JAMMIAH (Jurnal Ilmiah Mahasiswa Ekonomi Syariah), Volume 1, Nomor 2, September 2021 
lembaga perbankan yang selaras dengan sistem nilai dan etos islam. Dengan kata lain, bank syariah ialah "lembaga keuangan atau perbankan yang operasional dan produknya dikembangkan berlandaskan syariat Islam (al-Qur'an dan Hadis Nabi saw) dan menggunakan kaidah-kaidah fiqh, bahkan diartikan juga sebagai lembaga keuangan yang usaha pokoknya memberikan pembiayaan dan pelayanan yang lain, atau peredaran uang yang pelaksanaannya disesuaikan dengan asas Islam ${ }^{8}$.

Menurut Undang-Undang Nomor 21 Tahun 2008 Tentang Perbankan Syariah, pengertian perbankan syariah adalah segala sesuatu yang menyangkut tentang bank syariah dan Unit Usaha Syariah (UUS), yang mencakup kelembagaan, kegiatan usaha, serta cara dan proses dalam melaksanakan kegiatan usahanya. Bank syariah menjalankan kegiatan usahanya berdasarkan prinsip syariah yang menurut jenisnya terdiri dari ${ }^{9}$ :

1. Bank Umum Syariah (BUS) adalah bank syariah yang berdiri sendiri sesuai dengan akta pendiriannya, bukan merupakan bagian dari bank konvensional.

2. Bank Pembiayaan Rakyat Syariah (BPRS) adalah bank syariah yang dalam kegiatannya tidak memberikan jasa dalam lalu lintas pembayaran.

3. Unit Usaha Syariah (UUS) adalah unit kerja dari kantor pusat bank konvensional yang berfungsi sebagai kantor induk dari kantor atau unit yang melaksanakan kegiatan usaha berdasarkan prinsip syariah, atau unit kerja di kantor cabang dari suatu bank yang berkedudukan di luar negeri yang melaksanakan kegiatan usaha secara konvensional yang berfungsi sebagai kantor induk dari kantor cabang pembantu syariah atau unit syariah.

Dari berbagai definisi di atas, penulis menyimpulkan bahwa Bank Syariah adalah bank yang menjalankan kegiatan usahanya berdasarkan prinsip syariah dan menurut jenisnya terdiri atas Bank Umum Syariah ( BUS ), Unit Usaha Syariah ( UUS ), dan Bank Pembiayaan Rakyat Suariah ( BPRS ).

\section{Asas, Fungsi, dan Tujuan Bank Syariah}

Menurut Ismail asas, fungsi, dan tujuan Bank Syariah terbagi sebagai berikut ${ }^{10}$ :

${ }^{8}$ Nurmay Zura Rapika, “Analisis Faktor--Faktor Yang Mempengaruhi Nasabah Muslim Menabung Pada Bank Konvensional (Studi Kasus Nasabah Muslim Desa Sitorajo Kari Pada Bank Konvensional Diteluk Kuantan)," JUHANPERAK 2, no. 2 (2021).

${ }^{9}$ Nurimansyah Setivia Bakti, “Analisis DPK, CAR, ROA Dan NPF Terhadap Pembiayaan Pada Perbankan Syariah," Jurnal Bisnis Dan Manajemen (Journal of Business and Management) 17, no. 2 (2017): 15-28.

${ }^{10}$ Achmad Agus Yasin Fadli, "Pengaruh Financing to Deposit Ratio (FDR) Dan Non-Performing Financing (NPF) Terhadap Bagi Hasil Deposito Mudharabah Pada Bank Syariah Mandiri," Jurnal Maksipreneur: Manajemen, Koperasi, Dan Entrepreneurship," Jurnal Maksipreneur: Manajemen, Koperasi, Dan Entrepreneurship 8, no. 1 (2018).

JAMMIAH (Jurnal Ilmiah Mahasiswa Ekonomi Syariah), Volume 1, Nomor 2, September 2021 


\section{Asas-asas Bank Syariah}

a. Asas Falsafah

Allah tidak meninggalkan manusia sendirian tetapi diberikannya petunjuk melalui Rasul-rasul-Nya. Dalam petunjuk ini, allah memberikan segala sesuatu secara utuh, baik aqidah, akhlak, maupun syariah. Namun, syariah islam sebagai suatu syariat yang dibawa Rasul terakhir mempunyai keunikan tersendiri yaitu komprehensif dan universal. Sifat-sifat istimewa ini amat diperlukan karena tidak akan ada syariat lain yang datang untuk menyempurnakannya. Komprehensif berarti ia merangkum seluruh aspek kehidupan baik ritual maupun sosial (ibadah maupun muamalah). Sifat muamalah ini dimungkinkan karena adanya apa yang dinamakan prinsip dan fleksibel dalam Islam. Jika mengambil contoh dari sektor ekonomi sebagai prinsip, ketentuan dasar ekonomi bisa diambil seperti larangan riba, adanya prinsip bagi hasil, prinsip pengambilan keuntungan, dan lain-lain. Contoh ketentuan yang fleksibel merupakan instrumen-instrumen untuk melaksanakan bentuk muamalah seperti mudharabah, murabahah, dan sebagainya.

Dengan demikian, dasar falsafah segala aktivitas dalam Islam termasuk persoalan aktivitas perbankan adalah mencari keridhoan Allah untuk memperoleh kebaikan di dunia dan akhirat. Oleh karena itu, setiap aktivitas lembaga keuangan yang dikhawatirkan berbeda dengan tuntutan agama harus dielakan.

\section{b. Asas Pengoperasian}

Asas pengoperasian perbankan syariah dalam menjalankan produknya sebagai berikut ${ }^{11}$ :

1) Asas Wadiah (Penitipan)

Al-wadiah diartikan sebagai penitipan murni dari satu pihak kepada pihak lain, baik individu maupun badan hukum yang harus dijaga dan dikembalikan apabila pemilik barang menghendakinya. Secara umum, terdapat dua jenis wadiah, yaitu :

a) Al-Wadiah yad al-Amanah (Titipan pada Pemegang Amanah)

b) Al-Wadiah yad al-Dhamanah (Titipan pada Penjamin)

2) Asas Bagi Hasil (Profit and Loss Sharing)

11 Afrida Putritama, "Penerapan Etika Bisnis Islam Dalam Industri Perbankan Syariah," Nominal: Barometer Riset Akuntansi Dan Manajemen 7, no. 1 (2018): 1-20.

JAMMIAH (Jurnal Ilmiah Mahasiswa Ekonomi Syariah), Volume 1, Nomor 2, September 2021 
Asas bagi hasil dalam perbankan syariah bisa dilakukan dalam empat akad, yaitu $^{12}$ :

\section{a) Musyarakah}

Musyarakah ialah akad kerjasama antara dua pihak atau lebih untuk suatu usaha tertentu di mana setiap pihak memberikan kontribusi dana dengan kesepakatan bahwa keuntungan dan risiko akan ditanggung bersama sesuai dengan kesepakatan. Secara umum, musyarakah dibagi dua bagian, yaitu :

(1) Musyarakah pemilikan yaitu musyarakah tanpa akad yang tercipta karena warisan, wasiat atau keadaan lain yang mengakibatkan pemilikan satu aset oleh dua orang atau lebih.

(2) Musyarakah akad yaitu musyarakah yang tercipta karena kesepakatan dua orang atau lebih, di mana masing-masing memberikan modal musyarakah dan berbagi keuntungan dan

kerugian.

\section{b) Mudharabah}

Mudharabah ialah akad kerjasama usaha antara dua pihak di mana pihak pertama (shahibul maal) menyediakan seluruh (100\%) modal, manakala pihak lain menjadi pengelola (mudharib). Secara umum, mudharabah terbagi menjadi dua bagian, yaitu: ${ }^{13}$

\section{(1) Mudharabah Muthlaqah}

Mudharabah muthlaqah ialah bentuk kerjasama antara shahibul maal dan mudharib yang cakupannya sangat luas dan tidak dibatasi oleh spesifikasi jenis usaha, masa, dan kawasan bisnis.

\section{(2) Mudharabah Muqayyadah}

Mudharabah muqayyadah ialah keterbalikan dari mudharabah muthlaqah. Mudharib dibatasi oleh jenis usaha, masa, dan tempat usaha.

3) Asas Tijarah (Jual Beli)

12 Wirdayani Wahab, "Pengaruh Tingkat Bagi Hasil Terhadap Minat Menabung Di Bank Syariah," JEBI (Jurnal Ekonomi Dan Bisnis Islam) 1, no. 2 (2016): 167-84.

${ }^{13}$ Eka Jati Rahayu, "Mitigasi Resiko Akad Pembiayaan Mudharabah Pada Perbankan Syariah," Muqtasid: Jurnal Ekonomi Dan Perbankan Syariah 4, no. 1 (June 1, 2013): 55, https://doi.org/10.18326/muqtasid.v4i1.55-73.

JAMMIAH (Jurnal Ilmiah Mahasiswa Ekonomi Syariah), Volume 1, Nomor 2, September 2021 


\section{a) Murabahah}

Murabahah ialah jual beli barang pada harga asal dengan tambahan keuntungan yang disepakati ${ }^{14}$.

\section{b) Bay al-Salam}

Disebut salam karena pemesan barang menyerahkan uang di tempat akad. Ia disebut juga sebagai salafa karena pemesan barang menyerahkan uangnya terlebh dahulu. ${ }^{15}$ Secara istilah, salam diartikan dengan akad pesanan barang yang disebutkan sifat-sifatnya. Dalam pengertian lain bay salam berarti pembelian barang yang diserahkan di kemudian hari, tetapi pembayaran dilakukan di awal.

\section{c) Bay al-Istishna}

Bay al-Isthisna merupakan kontrak penjual antara pembeli degan pembuat barang. Dalam pelaksanaan, pembiayaan Istishna juga digolongkan kepada transaksi jual beli angsuran, seperti jual beli murabahah. Perbedaanya, dalam murabahah barang diserahkan dahulu dan pembayarannya dilakukan secara angsur sedangkan pada istisna barangnya diserahkan kemudian, dibayarkan secara angsur juga ${ }^{16}$.

4) Asas Sewa (Ijarah)

Ijarah menurut bahasa berasal dari kata ajru yang berarti iwad (ganti dan upah). Sedangkan menurut istilah, al-ijarah ialah akad pemindahan hak guna atas barang atau pelayanan melalui pembayaran upah/sewa, tanpa diikuti dengan pengalihan kepemilikan atas barang itu sendiri ${ }^{17}$.

5) Asas Pelayanan (al-Ajr)

Bentuk produk yang berdasarkan asas ini antara lain :

a) Al-Wakalah

Wakalah berarti penyerahan, atau pemberian kuasa. Dalam hal ini pelimpahan kekuasaan oleh seseorang kepada yang lain dalam hal-hal yang diwakilkan.

\section{b) Al-Kafalah}

Al-Kafalah ialah akad pemberian jaminan yang diberikan satu pihak kepada pihak yang lain di mana pemberi jaminan bertanggungjawab atas

14 Efrita Norman and Idha Aisyah, "Bisnis Online Di Era Revolusi Industri 4.0 (Tinjauan Fiqih Muamalah)," Al-Kharaj: Jurnal Ekonomi, Keuangan \\& Bisnis Syariah 1, no. 1 (2019): 30-44.

${ }^{15}$ Rahayu, "Mitigasi Resiko Akad Pembiayaan Mudharabah Pada Perbankan Syariah."

${ }^{16}$ Norman and Aisyah, "Bisnis Online Di Era Revolusi Industri 4.0 (Tinjauan Fiqih Muamalah)."

${ }^{17}$ A Hasyim Nawawie and others, "Kompleksitas Pembiayaan Ijarah Multijasa Dalam Fatwa Dewan Syari'ah Nasional Nomor 44 Tahun 2004 Perspektif Fiqh Muamalah Maliyyah," Jurnal At-Tamwil: Kajian Ekonomi Syariah 3, no. 1 (2021): 26-49.

JAMMIAH (Jurnal Ilmiah Mahasiswa Ekonomi Syariah), Volume 1, Nomor 2, September 2021 
pembayaran kembalinya suatu utang yang menjadi hak penerima jaminan.

c) Al-Hiwalah

Al-Hiwalah ialah pemindahan utang dari deposan atau peminjam kepada orang lain yang wajib menanggungnya dimana ada komisi atau upah yang dikenakan untuk pelayanan tersebut.

d) Al-Rahn

Al-Rahn ialah menahan salah satu harta milik si peminjam sebagai jaminan atas pinjaman yang diterimanya.

e) Al-Qard

Al-Qard ialah pemberian harta kepada orang lain yang bisa di tagih ata $\mathrm{u}$ diminta kembali atau dengan kata lain meminjamkan tanpa mengharapkan imbalan.

\section{Fungsi Bank Syariah}

Kegiatan bank syariah secara garis besar dapat dibagi menjadi tiga fungsi utama yaitu : penghimpunan dana pihak ketiga, penyaluran dana kepada pihak yang membutuhkan, dan pelayanan jasa bank ${ }^{18}$.

a. Penghimpunan Dana dari Masyarakat

Bank umum syariah menghimpun dana dari masyarakat dengan cara menawarkan berbagai jenis produk pendanaan antara lain giro, tabungan, dan deposito.

b. Penyaluran Dana Kepada Masyarakat

Bank syariah dapat menyalurkan dananya dalam bentuk pembiayaan serta dalam bentuk penempatan dana lainnya. Dengan aktivitas penyaluran dana ini bank syariah akan memperoleh pendapatan dalam bentuk margin keuntungan bila menggunakan akad jual beli, bagi hasil bila menggunakan akad kerjasama usaha, dan sewa bila menggunakan akad sewa menyewa.

c. Pelayanan Jasa

Bank syariah juga menawarkan produk pelayanan jasa untuk membatu transaksi yang dibutuhkan oleh pengguna jasa bank syariah. Hasil yang diperoleh bank atas pelayanan jasa bank syariah yaitu berupa pendapatan fee.

${ }^{18}$ Sri Deti et al., "Kontribusi Perbankan Syariah Terhadap Pertumbuhan Ekonomi Di Kabupaten Sambas," Jurnal Diskursus Islam 5, no. 2 (2017): 261-82.

JAMMIAH (Jurnal Ilmiah Mahasiswa Ekonomi Syariah), Volume 1, Nomor 2, September 2021 


\section{Tujuan Bank Syariah}

Secara umum, tujuan utama bank syariah ialah mendorong dan mempercepat kemajuan ekonomi suatu masyarakat atau bangsa, dengan melakukan aktivitas perbankan, keuangan, dan investasi sesuai dengan asas Islam. Upaya ini harus didasari dengan ${ }^{19}$ :

a. Larangan atas bunga pada setiap transaksi;

b. Asas kerekanan (partnership) pada semua aktivitas bisnis yang berdasarkan keadilan dan kejujuran;

c. Hanya mencari keuntungan yang halal dan sah;

d. Mengembangkan manajemen keuangan yang sehat;

e. Dan pembentukan jaringan kerjasama (networking) dengan lembaga keuangan Islam lainnya.

\section{D.Perbandingan Penelitian Terdahulu}

Penelitian Mekanisme Pembiayaan Pemilikan Kendaraan Bermotor iB Maslahah dilakukan oleh peneliti sebelumnya seperti yang dilakukan oleh Muhammad Anshori khairudin. ${ }^{20}$ Hasil dari penelitian menunjukan perbedaan antara produk amanah yang menggunakan akad rahn tasjily dengan jenis keuntungan $m u^{\prime} n a h$ 0,9\% per bulan(10,8\%/ tahun) dari harga kendaraan, pemberian jangka waktu 3 bulan untuk penanganan gagal bayar. Sedangkan produk PPKB iB Maslahah yang menggunakan akad murabahah dengan jenis keuntungan margin $14 \%$ per tahun dari sisi pokok pinjaman jangka waktu angsuran untuk penanganan gagal bayar. Untuk pelunasan hutang lebih awal PPKB iB Maslahah dinilai lebih menguntungkan disbanding Amanah. Dan kedua produk tersebut menggunakan metode flat dalam penentuan pembayaran angsuran bulannya. Adapun Hasil penelitian ini menjelaskan bahwa pembiayaan pemilikan kendaraan sepeda motor yang dimana calon nasabah harus memberikan simpanan wajib dan pokok sebagai pendaftaran calon nasabah Bank BJB Syariah, kemudian melengkapi persyaratan-persyaratan yang ada, dan juga melengkapi identitas diri si pemohon pembiayaan. pendaftaran Nasabah baru dengan memberikan simpanan wajib dan pokok serta memberikan uang muka sebesar 30\% dari jumlah harga sepeda motor. Sisa 70\% di angsur sesuai dengan kesepakatan di awal antara nasabah dengan pihak Bank.

${ }^{19}$ Raja Ria Yusnita, “'Analisis Perbandingan Pembiayaan Murabaha Pada Bank BRI Syariah, Bank Mega Syariah Dan Bank Syariah Mandiri (Studi Pada Bank Umum Syariah Yang Terdaftar Di Indonesia Periode Tahun 2012-2016),'" Jurnal Tabarru': Islamic Banking and Finance 1, no. 1 (n.d.).

${ }^{20}$ Muhammad Anshori. Khairudin, “Studi Komparasi Pembiayaan Kepemilikan Kendaraan Bermotor Pada Pegadaian Syariah Dan BCA Syariah Di Yogyakarta." (UIN Sunan kalijaga., n.d.).

JAMMIAH (Jurnal Ilmiah Mahasiswa Ekonomi Syariah), Volume 1, Nomor 2, September 2021 http://journal.sties-purwakarta.ac.id/index.php/jammiah/ ISSN: 2797-040X (Media Online) 2797-197X (Media Cetak) 
Selanjutnya penelitian dilakukan oleh Sandhi Ahmad ${ }^{21}$. Hasil penelitian menjelaskan bahwa pengaturan pembiayaan konsumen diatur dalam ketentuan Pasal 1320 Kitab Undang-Undang Hukum Perdata, Undang-Undang Nomor 42 Tahun 1999 Tentang Jaminan Fidusia, Peraturan Menteri Keuangan Nomor 130/PMK.010/2012 Tentang Pendaftaran Jaminan Fidusia dan Peraturan Presiden Republik Indonesia Nomor 9 Tahun 2009 Tentang Lembaga Pembiayaan. Dari adanya perjanjian ini maka hak dan kewajiban diantara para pihak tersebut menciptakan suatu tanggung jawab bagi para pihak, yakni perusahaan pembiayaan konsumen bertanggung jawab terhadap klaim asuransi dari pihak konsumen. sedangkan, pihak konsumen bertanggung jawab penuh atas keberadaan dan kondisi keutuhan barang atau benda jaminan tersebut. Adapun Hasil penelitian ini menjelaskan bahwa pembiayaan pemilikan kendaraan sepeda motor yang dimana calon nasabah harus memberikan simpanan wajib dan pokok sebagai pendaftaran calon nasabah Bank BJB Syariah, kemudian melengkapi persyaratan-persyaratan yang ada, dan juga melengkapi identitas diri si pemohon pembiayaan. pendaftaran Nasabah baru dengan memberikan simpanan wajib dan pokok serta memberikan uang muka sebesar $30 \%$ dari jumlah harga sepeda motor. Sisa $70 \%$ di angsur sesuai dengan kesepakatan di awal antara nasabah dengan pihak Bank.

Penelitian selanjunya dilakukan oleh Novita Ekasari ${ }^{22}$. Hasil penelitian menjelaskan bahwa Seiring dengan pertumbuhan ekonomi dan perkembangan teknologi, maka dunia Usaha pun mengalami perkembangan yang pesat dengan munculnya berbagai Perusahaan yang berusaha menciptakan produk dan jasa guna memenuhi kebutuhan dan keinginan konsumen. Maraknya bisnis finance atau pembiayaan konsumen (consumer finance) menimbulkan banyaknya pesaingpesaing baru yang bermunculan di Jambi dan tidak hanya menawarkan differensiasi tetapi juga sumber pendanaan yang kuat. Teknik analisis data yang digunakan yaitu analisis statistik deskriptif dan analisis regresi linear berganda. menunjukkan bahwa variabel pengetahuan dan pemahaman wajib pajak tentang peraturan perpajakan, kesadaran wajib pajak, kualitas pelayanan, dan sanksi perpajakan mempunyai pengaruh yang signifikan terhadap kepatuhan wajib pajak kendaraan bermotor yang terdaftar di Kantor Bersama Samsat Kota Malang. Adapun Hasil penelitian ini menjelaskan bahwa pembiayaan pemilikan kendaraan sepeda motor yang dimana calon nasabah harus memberikan simpanan wajib dan pokok sebagai pendaftaran

${ }^{21}$ Sandhi Ahmad, "Tinjauan Yuridis Tentang Lembaga Pembiayaan Konsumen Dalam Pembelian Kendaraan Bermotor," Jurnal Ilmiah, 2017.

${ }^{22}$ Et Al. Ekasari, Novita, "Pengaruh Promosi Berbasis Sosial Media Terhadap Keputusan Pembelian Produk Jasa Pembiayaan Kendaraan Pada PT. BFI Finance Jambi.," Jurnal Penelitian Universitas Jambi: Seri Humaniora, 2014.

JAMMIAH (Jurnal Ilmiah Mahasiswa Ekonomi Syariah), Volume 1, Nomor 2, September 2021 
calon nasabah Bank BJB Syariah, kemudian melengkapi persyaratan-persyaratan yang ada, dan juga melengkapi identitas diri si pemohon pembiayaan. pendaftaran Nasabah baru dengan memberikan simpanan wajib dan pokok serta memberikan uang muka sebesar 30\% dari jumlah harga sepeda motor. Sisa 70\% di angsur sesuai dengan kesepakatan di awal antara nasabah dengan pihak Bank.

\section{HASIL DAN PEMBAHASAN}

\section{A.Mekanisme Pembiayaan Pemilikan Kendaraan Bermotor (PPKB) iB Maslahah Di PT. Bank BJB Syariah KCP Cikampek}

Pembiayaan Pemilikan Kendaraan Bermotor iB maslahah merupakan Fasilitas Pembiayaan yang diberikan kepada nasabah individu (perorangan) untuk membeli kendaraan bermotor (mobil/motor). Mekanisme pembiayaan PPKB yang harus dipenuhi oleh calon Nasabah yang ingin mengajukan pembiayaan PPKB iB Maslahah pada BJB Syariah, Berdasarkan hasil penelitian di Bank BJB Syariah KCP Cikampek diantaranya sebagai berikut :23

1. Calon Nasabah yang ingin mengajukan permohonan pembiayaan ini terlebih dahulu dengan mengisi formulir pendaftaran dan menyerahkan fotokopi KTP.

2. Selanjutnya mengisi formulir pengajuan pembiayaan dilengkapi dengan fotokopi KTP Suami/istri. Dalam tahap ini dimulailah akad Murabahah antara petugas Bank dengan nasabah pengajuan pembiayaan.

3. Petugas bank memeriksa kelengkapan administrasi dan non administrasi nasabah yang ingin mengajukan pembiayaan,

4. Jika memenuhi syarat,petugas menanyakan kendaraan jenis apa yang diinginkan nasabah dengan menanyakan ke nasabah atau bersama-sama nasabah menuju dealer motor yang telah berkerja sama dengan Bank bjb syriah dan jika tidak memenuhi syarat maka pihak bank bisa memberikan penolakan kepada nasabah secara lisan ataupun tertulis.

5. Jika memiliki kendaraan, nasabah diminta membayar uang muka sebesar $30 \%$ dari harga jual kendaraan tersebut kepada bank lalu bank membelikan kendaraan tersebut secara lunas dari dealer

6. Selanjutnya nasabah membayar sisa kekurangan dengan cara mengangsur sebesar $70 \%$ harga jual kendaraan ditambah dengan mark up (keuntungan) yang telah ditentukan Bank. Mark up (keuntungan) sebesar 20\% dari nilai pembiayaan. Atau dari harga jual sepeda motor dikurangi uang muka dari nasabah pengajuan pembiayaan

23 “Bank Jabar Banten, Annual Report,” http:/www.bjbsyariah.co.id/, 2020.

JAMMIAH (Jurnal Ilmiah Mahasiswa Ekonomi Syariah), Volume 1, Nomor 2, September 2021

http://journal.sties-purwakarta.ac.id/index.php/jammiah/

ISSN: 2797-040X (Media Online) 2797-197X (Media Cetak) 
7. BPKB kendaraan yang telah dibeli tersebut dipegang oleh Bank sebagai jaminan yang telah disertai dengan surat kuasa pemegangan BPKB dari Nasabah yang mengajukan pembiayaan.

8. Akhir pembiayaan : Jika nasabah ingin melunasi secara tunai walaupun periode angsuran masih berjalan maka nasabah hanya membayar sisa kekurangan pembiayaan ditambah dengan mark up (keuntungan) bulan tersebut dan BPKB diserahkan ke nasabah dan Jika nasabah melunasi secara angsuran yang disepakati maka BPKB diserahkan diakhir periode angsuran. Jika nasabah tidak sanggup membayar sisa angsuran selama 1 bulan maka pihak bank memberikan toleransi, jika sampi 2 bulan maka pihak bank memberikan peringatan secara lisan atau tertulis, jika selama 3 bulan nasabah tidak membayar angsuran maka pihak bank akan mengeksekusi jaminan yang digunakan untuk menutup kekurangan pembiayaan ${ }^{24}$

Pembiayaan pemilikan kendaraan sepeda motor ini termasuk dalam akad Murabahah atau jual-beli. Dalam arti bahasa Murabahah diambil dari kata arab arribhu yang artinya tambahan atau keuntungan, pihak BMT disini sebagai penjual telah mengambil keuntungan yang telah diketahui oleh anggota selaku pembeli kendaraan sepeda motor, hal ini telah sesuai dengan fatwa DSN (Dewan Syariah Nasional) MUI (Majelis Ulama Indonesia) Tentang MurabahahNo.04/DSNMUI/IV/2000 yang tertulis 25: "bank harus memberitahukan harga pokok dan harga tambahan secara jujur kepada anggota/nasabah".

Praktek pembiayaan pemilikan kendaraan sepeda motor adalah dengan melengkapi segala persyaratan-persyaratan administrasi maupun non-administrasi, diantaranya yakni melengkapi identitas diri dan simpanan pokok serta wajib di Bank BJB Syariah KCP Cikampek. Menurut penulis identitas diri di perlukan untuk memenuhi persyaratan dari pihak penjual motor, dan simpanan wajib serta pokok digunakan untuk jaminan sebagai Nasabah. Kemudian, persyaratan yang lain yakni membayar 30\% dari jumlah harga motor sebagai uang muka sebagai bukti kesungguhan dalam meminta pembiayaan ${ }^{26}$. Nasabah serta petugas Bank pergi bersama-sama ke dealer yang bekerja sama dengan pihak Bank untuk memesan sepeda motor, menurut penulis hal ini dilakukan karena selera Nasabah berbe-beda

24 “Bank Jabar Banten, Annual Report,."

${ }^{25}$ Muhammad Abduh Robit Hudaya, "Implementasi Akad Murabahah Pada Pembiayaan Kepemilikan Kendaraan Bermotor Roda Empat Di PT. Bank Syariah Mandiri Kantor Area Malang." (Universitas Islam Negeri Maulana Malik Ibrahim., n.d.).

${ }^{26}$ Muhammad. Padli, “Pembiayaan Kepemilikan Kendaraan Bermotor IB Pada Bank BRI Syariah Kantor Cabang Pembantu Pasar Baru Banjarmasin." (. Institut Agama Islam Negeri Antasari Banjarmasin, 2016).

JAMMIAH (Jurnal Ilmiah Mahasiswa Ekonomi Syariah), Volume 1, Nomor 2, September 2021 
sehingga nasabah ikut untuk memilih sendiri motor yang diinginkanya, agar pembiayaan yang diinginkanya sesuai dengan harapan Nasabah.

Pembiayaan Pemilikan Kendaraan Bermotor iB maslahah merupakan Fasilitas pembiayaan yang diberikan kepada nasabah individu (perorangan) untuk membeli kendaraan bermotor (mobil/motor). Persyaratan nasabah diantaranya sebagai berikut: ${ }^{27}$

a. Warga Negara Indonesia (WNI) dengan status karyawan tetap, professional atau pengusaha

b. Usia minimum pada saat pengajuan pembiayaan 21 tahun

c. Usia maksimum pada saat jatuh tempo pembiayaan :

1. Karyawan : Maks 60 tahun

2. Professional dan pengusaha : Maks 65 tahun

3. Pegawai Negara sipil : sesuai dengan peraturan yang berlaku mengenai usia pension pegawai Negara sipil

d. Memiliki pengalaman kerja minimum :

1). Karyawan : 2 tahun (termasuk pekerjaan sebelumnya)

2). Professional dan pengusaha : 3 tahun dalam bidang yang sama.

Contoh penghitungan nilai pembiyaan dan angsuran: Nasabah mengajukan permohonan pembiayaan kepemilikan kendaraan sepeda motor dengan jenis kendaraan X, dengan harga dealer sebesar Rp 15.000.000, lama angsuran selama 1 tahun atau 12 bulan. Bank bersedia memberikan pembiayaan dengan syarat uang muka pembiayaan minimal sebesar 30\% dari harga dealer sepeda motor tersebut yaitu sebesar Rp 4.500.000. Jika nasabah menyanggupi maka Bank akan membelikan sepeda motor tersebut ke dealer. Nilai pembiayaan yang terjadi diakad ini sebesar Rp 10.500.000 dari harga dealer dikurangi uang muka dari anggota ditambah dengan mark up (keuntungan) sebesar Rp 2.100 .000 atau 20\% dari nilai pembiayaan. Besar angsuran adalah nilai pembiyaan ditambah mark up (keuntungan) dibagi lamanya angsuran per bulan. Jadi per bulan angsurannya sebesar RP 1.050.000. per bulan.

Murabahah adalah jasa pembiayaan dengan mengambil bentuk transaksi jual beli dengan cicilan. Sedangkan menurut istilah murabahah adalah salah satu bentuk jual beli barang pada harga asal perolehan dengan tambahan keuntungan yang disepakati antara pihak Bank dan nasabah. Dalam murabahah, penjual menyebutkan harga pembelian barang kepada pembeli, kemudian mensyaratkan atas laba dalam jumlah tertentu ${ }^{28}$.

${ }^{27}$ Admin, "Http://Www.Bjbsyariah.Co.Id/Pemilikan-Kendaraan,” n.d.

${ }^{28}$ Nuraeni., "Penerapan Psak No. 102 (Revisi 2013) Tentang Pembiayaan Murabahah Pada Baitul Mal Wat Tamwil (Studi Kasus Pada Baitul Mal Wat Tamwil 'Ibaadurrahman Sukabumi)" (Universitas Muhammadiyah Sukabumi., n.d.).

JAMMIAH (Jurnal Ilmiah Mahasiswa Ekonomi Syariah), Volume 1, Nomor 2, September 2021 http://journal.sties-purwakarta.ac.id/index.php/jammiah/ ISSN: 2797-040X (Media Online) 2797-197X (Media Cetak) 
Pembiayaan murabahah merupakan perjanjian antara bank dengan nasabahnya. Perjanjian tersebut dalam bentuk pembiayaan pembelian atas sesuatu barang yang dibutuhkan oleh nasabah. Nasabah akan membayar kepada bank sesuai dengan waktu yang telah diperjanjikan (pada tanggal jatuh tempo) dan lazimnya pembiayaan ini merupakan pembiayaan yang pendek ${ }^{29}$.

sekema pembiayaan murabahah yang ditawarkan bank syariah mendapat sambutan dan antusiasme yang tinggi dari masyarakat (nasabah), sehingga skema murâbahah merupakan transaksi yang paling banyak diminati dan dipraktikkan dalam operasional perbankan syariah. Dalam tipe ini, bank membeli dahulu barang yang akan dibeli oleh nasabah setelah ada perjanjian sebelumnya. Setelah barang dibeli atas nama bank kemudian dijual ke nasabah dengan harga perolehan ditambah margin keuntungan sesuai kesepakatan bank dan nasabah ${ }^{30}$.

\section{KESIMPULAN}

Mekanisme Pembiayaan Pemilikan Kendaraan Bermotor iB Maslahah di PT. Bank Bjb Syariah yaitu Nasabah diwajibkan melengkapi persyaratan pembiayaan seperti identitas diri, pendaftaran Nasabah baru dengan memberikan simpanan wajib dan pokok serta memberikan uang muka sebesar 30\% dari jumlah harga sepeda motor. Sisa 70\% di angsur sesuai dengan kesepakatan di awal akad antara nasabah dengan pihak Bank. Nasabah boleh melunasi sisa pembiayaan sebelum akhir periode angsuran dengan membayar jumlah kekurangan ditambah dengan bagi hasil pada bulan pelunasan tersebut. Ketika nasabah tidak mampu melunasi maka akan diberikan keringanan dengan tambahan waktu tertentu. Dalam hal ini Mekanisme pembiayaan pemilikan kendaraan bermotor di Bank BJB Syariah sesuai dengan aturan-aturan syariah yang berlaku, yakni sesuai dengan dalil Al-Quran surat AlBaqarah ayat 275 tentang dihalalkanya jual beli serta fatwa DSN MUI Tentang Murabahah No.04/DSN-MUI/IV/2000.

\section{DAFTAR PUSTAKA}

Achmad Agus Yasin Fadli. "Pengaruh Financing to Deposit Ratio (FDR) Dan NonPerforming Financing (NPF) Terhadap Bagi Hasil Deposito Mudharabah Pada Bank Syariah Mandiri," Jurnal Maksipreneur: Manajemen, Koperasi, Dan Entrepreneurship." Jurnal Maksipreneur: Manajemen, Koperasi, Dan Entrepreneurship 8, no. 1 (2018).

${ }^{29}$ Amilis. Kina, “Mekanisme Penanganan Pembiayaan Murabahah Bermasalah Studi Pada BMT Syari'ah Pare.," Ejournal IAIN Tulungagung, 3.2: 393-4 (2017).

${ }^{30}$ Lukman Haryoso, "Penerapan Prinsip Pembiayaan Syariah (Murabahah) Pada BMT Bina Usaha Di Kabupaten Semarang.," Law and Justice 2.1: 79-89 (2017).

JAMMIAH (Jurnal Ilmiah Mahasiswa Ekonomi Syariah), Volume 1, Nomor 2, September 2021 http://journal.sties-purwakarta.ac.id/index.php/jammiah/ ISSN: 2797-040X (Media Online) 2797-197X (Media Cetak) 
Admin. "Http://Www.Bjbsyariah.Co.Id/Pemilikan-Kendaraan," n.d.

Ahmad, Sandhi. "Tinjauan Yuridis Tentang Lembaga Pembiayaan Konsumen Dalam Pembelian Kendaraan Bermotor." Jurnal Ilmiah, 2017.

Bakti, Nurimansyah Setivia. "Analisis DPK, CAR, ROA Dan NPF Terhadap Pembiayaan Pada Perbankan Syariah." Jurnal Bisnis Dan Manajemen (Journal of Business and Management) 17, no. 2 (2017): 15-28.

Baluntu, Nur Muhammad Lakdar. "Minat Karyawan Dalam Pembiayaan Kepemilikan Kendaraan Bermotor Melalui Produk Amanah." Jurnal Ilmiah AlSyir'ah 12.2. (2016).

“Bank Jabar Banten, Annual Report,." http:/www.bjbsyariah.co.id/, 2020.

Daga, Rosnaini, Nurfatwa Ismail, and Bahtiar Maddatuang. "Analisis Efektivitas Program Mandiri Dagang Untung Pada Pt. Bank Mandiri (Persero), Tbk. Kanwil Regional X Sulawesi Dan Maluku." SEIKO: Journal of Management $\backslash \mathcal{E}$ Business 3, no. 3 (2020): 65-78.

Deti, Sri, Sabri Samin, Amiruddin Amiruddin, and Kasjim Salenda. "Kontribusi Perbankan Syariah Terhadap Pertumbuhan Ekonomi Di Kabupaten Sambas." Jurnal Diskursus Islam 5, no. 2 (2017): 261-82.

Ekasari, Novita, Et Al. "Pengaruh Promosi Berbasis Sosial Media Terhadap Keputusan Pembelian Produk Jasa Pembiayaan Kendaraan Pada PT. BFI Finance Jambi." Jurnal Penelitian Universitas Jambi: Seri Humaniora, 2014.

Haryoso, Lukman. "Penerapan Prinsip Pembiayaan Syariah (Murabahah) Pada BMT Bina Usaha Di Kabupaten Semarang." Law and Justice 2.1: 79-89 (2017).

Hidayatulloh, Muhammad Syarif. "Mekanisme Pembiayaan Kepemilikan Kendaraan

Sepeda Motor Di KJKS BMT Al-Hikmah Ungaran Cabang Bandungan." Uin Walisongo, 2016.

Hudaya, Muhammad Abduh Robit. "Implementasi Akad Murabahah Pada Pembiayaan Kepemilikan Kendaraan Bermotor Roda Empat Di PT. Bank Syariah Mandiri Kantor Area Malang." Universitas Islam Negeri Maulana Malik Ibrahim., n.d.

Khairudin, Muhammad Anshori. "Studi Komparasi Pembiayaan Kepemilikan Kendaraan Bermotor Pada Pegadaian Syariah Dan BCA Syariah Di Yogyakarta." UIN Sunan kalijaga., n.d.

Kina, Amilis. "Mekanisme Penanganan Pembiayaan Murabahah Bermasalah Studi Pada BMT Syari' ah Pare." Ejournal IAIN Tulungagung, 3.2: 393-4 (2017).

Lawadi, Aldo Agustinus; Busro, Achmad; Priyono, Ery Agus. "Tinjauan Yuridis Terhadap Perjanjian Pembiayaan Kendaraan Bermotor Roda Empat Pada Lembaga Pembiayaan PT. BCA Finance." Diponegoro Law Journal 5.2: 1-14. 
(2016).

Maikel Ch Ottay and Stanly W Alexander. "Analisis Laporan Keuangan Untuk Menilai Kinerja Keuangan Pada PT. BPR Citra Dumoga Manado." Jurnal Emba: Jurnal Riset Ekonomi, Manajemen, Bisnis Dan Akuntansi 3 3, no. 1 (2015).

Malensang, Jek, Dolina L Tampi, and Wilfried S Manoppo. "Analisa Tingkat Kesehatan Bank Berdasarkan Pendekatan RBBR (Risk Based Bank Rating) Pada PT. Bank SulutGo Periode 2015-2018." Jurnal Administrasi Bisnis (JAB) 9, no. 1 (2019): 82-89.

Nawawie, A Hasyim, and others. "Kompleksitas Pembiayaan Ijarah Multijasa Dalam Fatwa Dewan Syari'ah Nasional Nomor 44 Tahun 2004 Perspektif Fiqh Muamalah Maliyyah." Jurnal At-Tamwil: Kajian Ekonomi Syariah 3, no. 1 (2021): 26-49.

Norman, Efrita, and Idha Aisyah. "Bisnis Online Di Era Revolusi Industri 4.0 (Tinjauan Fiqih Muamalah)." Al-Kharaj: Jurnal Ekonomi, Keuangan $\backslash \mathcal{E}$ Bisnis Syariah 1, no. 1 (2019): 30-44.

Nuraeni. “Penerapan Psak No. 102 (Revisi 2013) Tentang Pembiayaan Murabahah Pada Baitul Mal Wat Tamwil (Studi Kasus Pada Baitul Mal Wat Tamwil ‘Ibaadurrahman Sukabumi)." Universitas Muhammadiyah Sukabumi., n.d.

Nurmay Zura Rapika. "Analisis Faktor--Faktor Yang Mempengaruhi Nasabah Muslim Menabung Pada Bank Konvensional (Studi Kasus Nasabah Muslim Desa Sitorajo Kari Pada Bank Konvensional Diteluk Kuantan)." JUHANPERAK 2, no. 2 (2021).

Padli, Muhammad. "Pembiayaan Kepemilikan Kendaraan Bermotor IB Pada Bank BRI Syariah Kantor Cabang Pembantu Pasar Baru Banjarmasin." . Institut Agama Islam Negeri Antasari Banjarmasin, 2016.

Putritama, Afrida. "Penerapan Etika Bisnis Islam Dalam Industri Perbankan Syariah." Nominal: Barometer Riset Akuntansi Dan Manajemen 7, no. 1 (2018): 1-20.

Rahayu, Eka Jati. "Mitigasi Resiko Akad Pembiayaan Mudharabah Pada Perbankan Syariah." Muqtasid: Jurnal Ekonomi Dan Perbankan Syariah 4, no. 1 (June 1, 2013): 55. https://doi.org/10.18326/muqtasid.v4i1.55-73.

Raja Ria Yusnita. “'Analisis Perbandingan Pembiayaan Murabaha Pada Bank BRI Syariah, Bank Mega Syariah Dan Bank Syariah Mandiri (Studi Pada Bank Umum Syariah Yang Terdaftar Di Indonesia Periode Tahun 2012-2016),.'” Jurnal Tabarru': Islamic Banking and Finance 1, no. 1 (n.d.).

Rangkuti, Freddy. Personal Swot Analysis Peluang Di Balik Kesulitan. Jakarta: Gramedia, 2016.

Wahab, Wirdayani. "Pengaruh Tingkat Bagi Hasil Terhadap Minat Menabung Di 
Bank Syariah." JEBI (Jurnal Ekonomi Dan Bisnis Islam) 1, no. 2 (2016): 167-84. 